Vagueness and Archaeological Interpretation : A Sensuous Approach to Archaeological Knowledge Formation Through Finds Analysis

\title{
Marila, Marko
}

2017-06-14

Marila , M 2017 , ' Vagueness and Archaeological Interpretation : A Sensuous Approach to Archaeological Knowledge Formation Through Finds Analysis ', Norwegian Archaeological pÿReview , vol. 50 , no. 1 , pp. 6688 . https://doi.org/10.1080/00293652.2017.1325393

http://hdl.handle.net/10138/297769

https://doi.org/10.1080/00293652.2017.1325393

acceptedVersion

Downloaded from Helda, University of Helsinki institutional repository.

This is an electronic reprint of the original article.

This reprint may differ from the original in pagination and typographic detail.

Please cite the original version. 
Vagueness and Archaeological Interpretation. A Sensuous Approach to Archaeological Knowledge Formation Through Finds Analysis

\section{Marko Marila}

Department of Philosophy, History, Culture and Art Studies, Archaeology, University of Helsinki, P.O. Box 59, FI-00014, Helsinki, Finland

Telephone: 0294124223

E-mail: marko.marila@helsinki.fi

\section{Acknowledgements}

I am grateful to professors Visa Immonen and Mika Lavento, and docent Volker Heyd as well as the journal editors and referees for their comments on earlier versions of this paper. I also wish to thank Teemu Mökkönen and Kerkko Nordqvist for their insight into the practice of finds analysis, and photographer Maija Annikki Savolainen for visual consultancy. Naturally, all mistakes are mine.

\section{Abstract}

The rapid development of natural scientific methods coupled with the recent popularity of new materialist philosophies in archaeological theory has raised discussion about the possibility of a return to empiricism in archaeology. While empiricism as a pragmatic philosophy is in line with archaeology's hands-on character, the recent development has left some concerned about the vanishing role of vagueness and ambiguity in archaeological interpretation. In this setting, the exactitude of natural scientific methods is seen as a process of simplification that compromises the tacit dimensions of archaeological knowledge. This article discusses vagueness as an elementary part of all archaeological knowledge formation, with a particular emphasis on the role of perception and senses in finds analysis. Archaeological finds analysis is explored as an example of epistemologically vague and creative hypothesis formation.

Keywords: abduction; creativity; empiricism; epistemology; finds analysis; new materialism; ontology; senses; vagueness

Word count (main text): 8300 words

\section{Introduction}

Charles Peirce has famously noted in the empiricist fashion that the logical and the aesthetic are inseparable (Peirce 1934, p. 181). The aesthetic has been of special interest in archaeological 
theory since at least the early 1990s, mainly as a response to the discipline's tendency toward prioritising the analytical and the logical (Meredith 1990, Shanks 1992, Ingold 1993, Tilley 1994, Hamilakis et al. 2002, Cochrane and Russell 2007, Normark 2010, Day 2013, Hamilakis 2013, 2017, Gheorghiu and Bouissac 2015). The importance of the body and the senses in particular has been noted by archaeologists not only in respect to the past individual's experience of her lived world, but also as an important part of the archaeologist's experience in scientific practice. The role of the archaeologist's bodily and sensorial experience has mostly been studied in archaeology as an element of fieldwork, particularly in the context of excavation (Edgeworth 1990, 2012, Yarrow 2003). Post-excavation and finds analysis, however, and more importantly the formation of new archaeological knowledge through these practices, remains relatively little studied in this respect (see, however, Shelley 1996, MacGregor 1999, Cummings 2002, Witmore 2004, Lazzari 2005, Hurcombe 2007, Knappett 2007, Myrberg 2010).

This article explores the relationship between the vagueness of tacit sensory experience and the formation of new knowledge in archaeological finds analysis. Firstly, acknowledging the empirical nature of archaeology and the close relationship between materials, processes, and interpretation, the article responds to the recent discussion in archaeology on new empiricism and the related question of exact scientific methods versus vague interpretations. In the article, archaeological interpretation is seen as aesthetic emergence and processual becoming that is firmly rooted in the archaeological materials. Such an approach not only underscores the relevance of archaeological materials but also the processual nature of scientific discourse and the researcher's personal bodily and sensorial experience in the process of knowledge formation. In this respect, the article also wishes to draw attention to the discrepancies between the interpretative process and the transformation of information into scientific publications that tends to obscure vagueness' importance.

Secondly, the corporeal and the material are connected to the aesthetic and the cognitive by using Charles Peirce's concept of abductive inference. The concept of abduction is used to characterise vague low-level hypothesis formation. In doing so, the foundations of the logic of archaeological discovery are extended to include what can be referred to as the speculative dimension of research: aesthetics, senses, perception, feeling, creativity, and ambiguity. These concepts are loosely bundled together to represent the vague, but vital, dimension of archaeology's epistemology. The sense in which vagueness is referred to in this article highlights it as a counterpoint to any tendency to fully rationalise the components and process of archaeological knowledge formation: vagueness is experienced as the quality and tendency of any object to change according to perspective, and escape the exact and the rationalised, the written and the discursive (see, for example, Witmore 2009 discuss Serres 1995). The article wishes to underscore vagueness' role in archaeology by rooting it epistemologically in the open-endedness of archaeological interpretation. Abduction is seen as an empiricist 'logic of vagueness' (Chiasson 2001). Such position acknowledges vagueness as an inescapable research reality, but it also 
welcomes it as an epistemological resource for new knowledge. It treats also exact data as epistemically vague in the sense that its relevance can be perceived in different ways depending on the researcher's background knowledge, and that exact data is more likely to arise new research questions than provide definitive answers to existing ones.

\section{Archaeology's empiricisms and vagueness}

The heated debates around the nature and relevance of archaeological theory starting from or belonging to the post-processual shift have resulted in the conceptualisation of ideological grand theorising as more or less dead (Bintliff and Pearce 2011, Bintliff 2015, see Hillerdal and Siapkas 2015 for responses, and Lucas 2015a and comments). As result of the increasing fragmentation of archaeological theory, coupled with the increasing use of and reliance on natural scientific methods, a material- or data-based new empiricism has been proposed (Kolen 2011, Witmore 2012, 2015, Hillerdal and Siapkas 2015, Sørensen 2016). This naturally has raised questions about the future of archaeological theory. If we are now facing a return to archaeological empiricism, what is it that warrants the term new empiricism, and what distinguishes it from old empiricism?

In order to understand the implications of a return to empiricism it is perhaps necessary to contextualise what is happening against the history as well as the current state of archaeological theory and especially one of its defining subfields, epistemology. The history of archaeology's epistemology can be characterised in two terms as either naively inductivistic on the one hand, and explicitly scientific or positivistic and deductivistic on the other. Furthermore, after the change of focus in epistemological issues from logic to phenomenology in the archaeologies of the 1980s and 1990s, archaeology's epistemology can today be conceptualised roughly as either realist or (social) constructivist. In one sense this reflects the tiresome distinction between analytical and continental philosophies. Processual treatments of archaeology's epistemology, having adopted an analytical approach, tend to emphasise the clear and the cognitive, while postprocessual archaeologies' focus is on the corporeal and the vague. Despite many efforts to overcome these tiresome divisions, archaeological theory seems to remain distinctively polarised, and, in many ways, the concern for a return to empiricism resembles the critique presented by post-processualists against processualism's reliance on natural scientific methods (Kristiansen 2014). Those who wish to retain a degree of ambiguity as part of scientific archaeology, fear that this new empiricist attitude with its reliance on the ontological autonomy of things and exact and measurable data compromises the role of the aforementioned concepts (Gero 2007, 2015, Sørensen 2016).To a certain extent, the concern of new empiricism as an enemy of vagueness in archaeological theorising reflects the aforementioned philosophical divides, but it is also unwarranted because new forms of empiricism have little to do with their old inductivist or positivist-deductivist counterparts. 
Based on the aforementioned divisions, a distinction can be made between inductivist and deductivist old empiricism, and science-based and materialist new empiricism. I do not want to make too strong a distinction between different forms of new empiricism (in one sense empiricism never went away), but it is worth noting that there are different forms of new empiricism. Some can be seen as a return to naive or positivistic old empiricism that rely on the autonomy of exact data, while others, especially those inspired by forms of new materialist philosophies, are ontologically responsible, a point I elaborate below. The point I wish to make is that all forms of new empiricism incorporate forms of vagueness, whether acknowledged by individual researchers or not.

The problematisation of empiricism in archaeology dates back to the early days of scientific archaeology, and one can easily find the relevant literature treating the many roles and modes of empiricism in archaeology (e.g. Gibbon 1989, Wylie 2002, Johnson 2011, Hillerdal and Siapkas 2015). For that reason, I shall not attempt a recap of the history of empiricism, but rather explore the implications of adopting a new empiricist attitude in archaeology. I begin by discussing some defining philosophical distinctions between old and new empiricisms in archaeology.

Empiricism and the ontologisation of archaeology's epistemology

The defining way in which old empiricism is often understood in archaeology is the naive inductivist conviction that the data can speak for themselves with no need on the archaeologist's behalf to adhere to any particular theoretical tools to interpret the data (Johnson 2011). Archaeological objects and data become reduced to matters of fact. Critique of this simplistic idea of a face value of data formed the epistemological core of New Archaeology (e.g. Willey and Phillips 1958) and processualism (e.g. Binford 1981), and became exceedingly challenged during the 1980s as part of archaeology's poststructuralist treatments. In its most extreme forms, the increasing reliance on philosophy in archaeology resulted in author-driven hero worship (Shanks 1990). It is therefore not surprising that some theory-reformist (Bintliff and Pearce 2011) and especially new materialist (Olsen et al. 2012) approaches have been arguing for a return to things, both by means of philosophy and by reaffirming the relevance of archaeological materials and the practice of archaeology as a method of knowing by engaging and experiencing with the world rather than knowing of it (Shanks 1995, Shanks and McGuire 1996, Baines and Brophy 2006, Ingold 2013). These approaches reflect a wider shift from social constructivist approaches to different forms of new materialism. It should be noted that I refer to new materialism as a very broad concept with no reference to a particular theoretical stance or author. Rather new materialism should be understood as a general theoretical development that has taken place in archaeological theory, and humanities and art for that matter, during the recent 15 years.

Some philosophical strands of new materialist archaeologies have been criticised for their radical erasure of human interpretation (see Olsen and Witmore 2015 for summary and response). While 
it is true that some new materialist accounts can be seen to reflect the idea that interpretation could, or should, be avoided except in its modest and inevitable form (e.g. Olsen 2012, p. 22), new materialism's take on empiricism should not be seen as a return to the naive old empiricism. Such empiricism can be said to have been occupied with the binary correlation between the human observer and the thingly observed, or brute facts as the hard and the interpreter as the soft, but at the heart of the new materialist empiricism is another kind of consideration of the human-world relation. New empiricism's treatment of empiricism can in one sense be described as belonging to the wider shift in archaeological theory from epistemological issues to ontological concerns (Webmoor 2007, Webmoor and Witmore 2008, Alberti et al. 2011, 2013, Witmore 2012, Lucas 2015b, Alberti 2016).

The ontologisation of archaeology's epistemology has mainly been inspired by science and technology studies and actor-network theory (e.g. Knappett and Malafouris 2008, Witmore 2009, 2015, Webmoor 2013). These influences were most evidently seen in archaeology as the birth of symmetrical archaeology (Olsen 2003, Witmore 2006). Tim Webmoor (2007), one of symmetrical archaeology's proponents, sees archaeology's epistemology as problematic if it is practiced in the modernist fashion that presupposes a fundamental human-thing split. In this sense, Webmoor sees the many forms of positivist approaches as well as hermeneutics and phenomenology equally problematic. Symmetrical archaeology's solution to the problem was to adopt a flat ontology that acknowledges a similar divide between all things, not just between humans and things.

In addition to taking influences from science and technology studies and actor-network theory, archaeology's new ontologised empiricism, in its philosophical form, is to a large degree inspired by different forms of speculative realism. Although a wide and varied philosophical field mainly formulated as a post-humanist response to postmodernism and relativism, speculative realism often makes the claim that there is no one originary 'correlation' (Meillassoux 2008) between observer (human subject) and observed (object world), but rather that all objects (humans included) remain 'withdrawn' from their countless relations to other objects. Graham Harman, the philosopher to whom the concept of withdrawnness is usually referred has become a household name in archaeological theory (Harman 2005, p. 81-86, Olsen 2010, Alberti et al. 2011, Olsen et al. 2012, Witmore 2014, 2015, Fowler and Harris 2015, Thomas, J. 2015, Edgeworth 2016a, Ribeiro 2016).

The concept of withdrawnness does a fairly good job in establishing interpretation as an integral part of all relations, not only that between the human interpreter and the other. This means that, along with interpretation, such archaeologically important notions as meaning, and, more importantly, cognition, are not processes that take place at the human end of a 'bifurcated nature' (Whitehead 1978, p. 289-290), but are something that things share as well (Webmoor and Witmore 2008, Malafouris and Renfrew 2010, Edgeworth 2016a). 
The differences in the ways an archaeologist and a stream of melt water negotiate an abandoned mining town are of degree, not kind. Rushing water washing against concrete pillars will "interpret" or "feel" the concrete surface as well as any hermeneut or phenomenologist.' (Olsen et al. 2012, p. 10)

In other words, the imagined interpretative gap or epistemological divide between humans and objects is pluralised (Bryant 2011, p. 26, Witmore 2014). Because withdrawnness pervades all relations, all interpretation remains to a degree speculative. In this sense, any form of empiricism that adopts this approach to epistemology can be characterised as ontologically responsible. Put in the more explicit language of archaeology, the past is rendered a renewable resource in both ontological and epistemological sense (with apologies to the notion of past as renewable in the material sense). There is no beginning or end to the interpretation of the past because relations never exhaust their constituents. This is a key notion to understanding the fact that the archaeological record can be interpreted in many different ways.

Epistemology of vagueness

Despite new empiricism's strong devotion to speculative philosophies, the possibility of a new empiricism in archaeology is a concern to some supporting vagueness as an integral part of archaeology. Tim Flohr Sørensen (2016, p. 744) for example sees the increasing trust in and need of scientific and quantifiable data that has resulted from the rapid development of some natural scientific methods as synonymous with a return to old positivist empiricism in archaeology. In his view, there is no room for uncertainty, ambiguity, or vagueness in these so-called 'mechanisms of closure,' which aim to portray complex observations, and give simple answers to big research questions in form of neat and simplified representations (Gero 2007, 2015).

While Sørensen (2016) does not make a clear distinction between data-based empiricism and the ontologically responsible version, he identifies a fundamental divide in archaeology's methodology between natural sciences and humanities that has existed in Scandinavian archaeology since the latter part of the 19th century: archaeology's increasing reliance on natural scientific methods tends to render the methods of the humanities unreliable or unacceptable, unless corroborated by scientific 'facts.' This highlights the need to conceptualise exact data as inherently vague in the sense that it can be perceived in different ways. Above, I mentioned withdrawnness and the pluralisation of relations and interpretation as central to the new ontologically responsible version of empiricism. They both go further to highlight, as also hinted by Sørensen $(2015,2016)$, that there is plenty of room for vagueness and speculation in current post-humanist archaeology which has been held partly responsible for upholding the idea of a new archaeological empiricism, and therefore also unjustly criticised for leaving no room for the human interpreter, but also in exact natural scientific archaeologies. 
Because Sørensen's (2016) critique targets the type of empiricism that relies on the exactness of natural scientific methods rather than the ontologised version of new empiricism, the defining question for him is whether something is vague because things themselves are vague and vagueness is an ontological fact, or if things are ontologically clear and exact and the available methods are simply unable to perceive or describe things adequately. Sørensen points out that, in archaeology, vagueness is often seen as a research deficiency owing to incomplete or absent data or lack of knowledge rather than as an inherent quality of things and relations. As he puts it, ambiguity and uncertainty are part of archaeological realities, both past and present. Objects, including representations, can be vague not only because some related data is missing but because they can be perceived in two or more distinct ways. Often one would be inclined to think, in the positivist fashion, that precise methods give precise descriptions of things, and it remains a necessary condition for such positivism that things are assumed ontologically clear.

For some reason, we are often more resistant to ambiguity in our everyday life than we are in our study of past lives. Vagueness most likely played a similarly big role in past people's lives. As long as vagueness is experienced empirically, it is real, whether the experience is born out of our modern need to come up with neat compartmentalisations or not. This is the pragmatist's, as well as Sørensen's $(2012,2015,2016)$, answer to the question whether vagueness is an ontological or an epistemological fact: vagueness only makes sense as an empirical phenomenon.

While neat packaging of data may lead to the dismissal of some nuances that the recognition of vagueness probably would bring to light, the mechanisms of closure, however, rarely lead to actual closure. In fact, exact scientific data, archaeological datings for example, often, especially when their results are surprising, raise other questions about the materials. New methods, however exact, can revive old research trends, although in revised form, such as the case with isotope studies, genomics, and migration or mobility (Killick 2015, Burmeister 2016), but also radically change long-held or established views (Martinón-Torres and Killick, forthcoming). Any experienced archaeologist knows not to put too much emphasis on even the most exact data. In this sense, interpretations of exact data remain as open-ended and subject to revision as their vague counterparts. In other words, the assertion that any amount of exact data could close the case at hand and free us from speculation is contrary to the evidence and a reaffirmation of the old inductivist conceptualisation of the total archaeological record. Despite all the recent advances in scientific methodology, archaeology remains a speculative endeavour as opposed to a fundamentally exact science (Darvill 2015).

Ian Hodder's (2012) recent take on entanglement, for example, includes a method of mapping and displaying connections between things that preserves this open-endedness of interpretation. What Hodder calls tanglegrams are network analyses between material dependencies (in his example, at the site of Çatalhöyük). Although tanglegrams are elaborate depictions based on thousands of hours of meticulous fieldwork and precise archaeometry, Hodder acknowledges the open- 
endedness and contingent nature of these mappings. They summarise the research expressed in thousands of pages of text, and, in presenting the information in a compact form, they allow 'new patterns to be seen and further explored' (Hodder and Mol 2016, p. 1091), while remaining vague also in the sense that the connections could have been perceived in another way in the first place. Archaeological materials, then, can seem to change as a result of our changing conceptions of them (Hodder 1991, Sørensen 2016, Edgeworth 2016a). The development of aerial photography, for example, during the first half of the twentieth century, due to the different perspective, led to the discovery of new types of archaeological sites. Moreover, recent advances in LiDAR technologies offer similarly new perspectives to archaeological surveying. Acts of discovery are intimately connected to available scientific methodology.

\section{Abduction and the vagueness of perception}

'If [...] vagueness is a key constituent in the social life, then there is a need for an interpretative framework to allow vague phenomena to make sense. This is admittedly a difficult task, challenging the ordinary framework of archaeological theory and method, because it ordinarily considers vagueness an erratic borderline phenomenon. What I argue for, hence, is not an archaeology absent of meaning, data or conclusions, but instead a methodology capable of embracing the erosion of clarity.' (Sørensen 2016, p. 759.)

Archaeology has recently become increasingly inclusive in respect to what constitutes interpretation. As a result, some archaeologists are exploring the role of perception and senses in interpretation of archaeological materials (Hamilakis et al. 2002, Day 2013, Hamilakis 2013). Following this sentiment, as well as Sørensen's call for a methodology that embraces vagueness, I also wish to broaden archaeological interpretation to govern not only the logical in the epistemological sense, but also the perceptually vague as a fundamental element of scientific inquiry. In order to highlight the intimate connection between perception and hypotheses, or the empirical and the interpretative, I make use of Charles Peirce's concept of abductive inference. This aspect to abduction is central to Peirce's philosophy (Magnani 2004, p. 226, Tiercelin 2005), but it has been neglected in accounts of the formation of archaeological knowledge (see, however, Shanks 1996, p. 38, Shelley 1996). This approach aims at overcoming the traditional conceptualisation of perception as either directly connected to the real or as inferential and indirect (Haack 1994). It will showcase vagueness from a somewhat different perspective, and it also addresses the question raised above about the relationship between absence and vagueness.

\section{Abduction}

Abduction found its way to archaeology from philosophy of science where it is usually taken to mean one of two things. Firstly, it is a conceptual model for the formation of explanatory hypotheses, often referred to simply as abduction after Charles Peirce, and the logic of discovery 
in reference to Norwood Russell Hanson's (1958) use of the concept. Secondly, it is often used in connection with treatments of the logic of selecting the most plausible hypothesis out of many possible (Inference to the Best Explanation, or IBE), after Gilbert Harman (1965) and Peter Lipton (1991). For the distinction between abduction and IBE, see for example, Minnameier (2004), Paavola (2006), and Campos (2011).

The concept's use in archaeological theory varies greatly. Many have implicitly or explicitly referred to abduction when discussing IBE as a model of hypothesis formation and/or selection (Plog 1974, Kelley and Hanen 1988, Hanen and Kelley 1989, Routledge 1995, Fogelin 2007, Chadha 2010, Bogaard 2015, Dallas 2016). Some accounts make use of the term in reference to Alfred Gell's (1998) 'abduction of agency' (Alberti 2001, Shapland 2010, Herva and Nordin 2015). Others use the concept in the context of digital or computational archaeology, such as model building, simulation, and artificial intelligence studies (Doran 1986, Madella et al. 2014), or Bayesian archaeology (Buck and Meson 2015). Many use the concept in connection with the analogy of crime scene investigation, detective reasoning, and jurisprudence (Shanks 1996, Klejn 2001, Pearson and Shanks 2001, Thomas, R.M. 2015). Abduction has even been used as a conceptual tool in discussing heritage practices and multivocality (Bauer 2013). Other significant works of interest, besides Peirce's original texts, might include Eco and Sebeok (1983) and Preucel (2006).

My approach to abduction, in this article, makes use of the concept in the Peircean sense with no explicit reference to IBE. In one way, I refer to abduction as a weak form of reasoning that governs the process of hypothesis formation at its most fundamental level. 'Abduction is [...] the only kind of argument which starts a new idea' (Peirce 1932, p. 96). The most obvious way in which abduction, then, differs from other forms of reasoning, namely induction (inference by enumeration and probability) and deduction (inference by necessity), is that in making an abductive inference 'we are bound to assume, independently of any evidence that it is true. Animated by that hope, we are to proceed to the construction of a hypothesis.' (Peirce 1958, p. 219.) In archaeology, induction simply allows us to generalise from a set of observations that share some kind of resemblance, while deductive arguments are purely mathematical or so banal that they are uninteresting archaeologically. Abduction, therefore, has a special role in archaeology due to the peculiarity or unexpectedness of some finds and the interconnectedness of a wide variety of materials and processes in the past.

Besides these rather logical formulations, abduction shares a close affinity with some of the ontological concerns discussed above, and as such acts as a bridging concept between the two domains. Embracing the recent development in archaeology after the 'speculative turn,' as well as the so-called process thinking inspired by such scholars as Bergson, Whitehead, and Peirce, archaeology's epistemology can be characterised as a philosophy of doing, becoming, linking, and connecting (Malafouris and Renfrew 2010, Robb 2013, Gosden and Malafouris 2015). Bearing also 
close resemblance to new materialism's ontologisation of archaeology's epistemology, abduction is a conceptualisation of the interpretative process of becoming that is instantiated through our relationships with other things. In general, Peircean semiotics holds in it the similar idea of pluralisation of interpretation that is an integral part of new materialism's conception of interpretation (Crossland and Bauer 2016). Abduction is not restricted to a human mind (Peirce 1933, p. 551, Magnani 2010) because '[t]hought is not necessarily connected with a brain. It appears in the work of bees, of crystals, and throughout the purely physical world; and one can no more deny that it is really there, than that the colours, the shapes, etc., of objects are really there.' (Peirce 1933, p. 551.)

In this sense, abduction, as a blending of mind and matter (Magnani 2014), enables us to transgress the distinction between vagueness as either an ontological or an epistemological quality. Abduction should be considered a mode of affordance-seeking that has developed evolutionarily in parallel with our perception and senses. 'From this perspective the world is experienced as giving various opportunities to carry out "habitual" actions, that is it provides what Gibson calls affordances: habits of action abductively "reveal" affordances' (Magnani 2009, p. 185, emphasis original). This dissolves the clear distinction between the real and the interpreted, and in doing so it goes to further radicalise the ontological and epistemological distinction between the past and the present, and the absent and the vague. Abductive inference is inference to that which is absent in experience. In other words, what we refer to as the present is just as fragmentary, vague, and open-ended as that which we refer to as the past in the present.

Abduction, perception, and creativity

Archaeological interpretation, in the psychological sense, takes all kinds of forms from intuitive understanding to more deliberate contemplation (Bintliff 2011, p. 21). But there is also a bodily and sensorial aspect to how we interpret. Abduction is central to understanding such processes that are fundamental to the formation of new knowledge, but which have been held impossible to analyse in the inductivist or positivist-empiricist framework. The hypothetico-deductive model, for instance, does not issue the formation of hypotheses, it only states that they are formed in a leapof-faith fashion through guessing or by chance (Copi 1953, p. 49, Plog 1974). It is then considered the responsibility of the logician to figure out what is the correct or most efficient form of selecting and testing existing hypotheses (falsification or confirmation).

Peirce, however, emphasised the experiential roots of hypothesis formation and maintained that the logical and aesthetic are inseparable, and perception is always interpretative: our perception and abductive inferences shade into one in a continuous process, and perceptual judgements should be considered an extreme case of abductive inference (Peirce 1934, p. 181). Much of the logical process, then, is not amenable to reason, but instead happens organically without our 
attention. This does not only highlight the intimate connection between abduction and induction, but also introduces instinct as part of logic. Peirce included instinct as an important part of hypothesis formation as an attempt to affirm that perceptual judgements are abductive and that the continuous process of making and revising these judgments is fundamental to our evolutionary existence: belief and doubt are 'bound together in a cycle' (Mullins 2002, p. 203). Facts that do not accord with our fixed beliefs are the prime source of doubt. Some refer to this process as dialectics or hermeneutics while others refer to it as tacit knowing, but I choose to call it abduction.

It is perhaps impossible to theorise about the relevance of perception and senses in relation to inference and instinct and not mention the many strands of phenomenology that place equal importance on the role of the body in our experience and perception. One common theme within phenomenology is to regard the body as an experiential background. In many ways, the body has been regarded as a background for consciousness and perception, but other approaches, such as Richard Shusterman's (2012) 'somaesthetics' aims at foregrounding the body not only as a tool to be used but lived-through: the body is a sedimentation of knowledge and experiences. The body has been extensively theorised from such phenomenological viewpoint in archaeology (e.g. Edgeworth 1991, Meskell 1996, Meskell and Joyce 2003, Tilley 2004, Olsen 2010, Back Danielsson 2015, Mizoguchi 2015).

Some phenomenological approaches highlight interpretation as a form of dwelling that connects us to the object of our making-sense-of (Ingold 1993, Gosden 2001, Jones 2006, Graves-Brown 2011, 2013, Olsen and Pétursdóttir 2014). In the context of archaeological materials, this makingsense-of becomes evident as we reorient ourselves between small details and a more holistic understanding of the materials, and get to know them more intimately. Perhaps, when talking about archaeological interpretation, it would therefore make more sense to speak of understanding rather than explanation. Explanation tends to evoke ideas of causal necessity and prediction, and as such the concept acts as a mechanism of closure, while understanding opens our mind for the possibilities that a particular set of materials, actors, and processes provided in the past (Barrett 2016a). This highlights the role of aesthetics as an ontological register (e.g. Harman 2007). Interestingly, Pétursdóttir and Olsen (2014, p. 15) refer to aesthetics and the perception of vagueness as an instinct, or a form of primitive materialism.

Because all relations are interpretative rather than causal, they should be conceptualized as loose or arbitrary, and their effects unexpected rather than mechanical and necessary. Thus, abduction, as "the "logic of vagueness" is the logic by which anomalies (those facts which are not yet noticed) come to be recognized, made sense of, and eventually generalized' (Chiasson 2001). Such aesthetic dwelling or understanding of the relations between parts and wholes rather than the explanation of their causal relations highlights the creative aspect of knowledge formation. 
The formation of new knowledge owes partly to our imagination in being able to resequence known facts, but also to the ability to think in counterfactual terms. This aspect to abduction was central to Peirce's understanding of the term:

'A mass of facts is before us. We go through them. We examine them. We find them a confused snarl, an impenetrable jungle. We are unable to hold them in our minds. We endeavor to set them down upon paper; but they seem so multiplex intricate that we can neither satisfy ourselves that what we have set down represents the facts, nor can we get any clear idea of what it is that we have set down. But suddenly, while we are poring over our digest of the facts and are endeavoring to set them into order, it occurs to us that if we were to assume something to be true that we do not know to be true, these facts would arrange themselves luminously. That is abduction.' (Peirce 1997, p. 282.)

The different elements of a novel idea may have been in our mind before but the novelty of this new idea owes to our ability to put together something in a radically new fashion (Peirce 1934, p. 181, Klejn 2001, p. 81-82, Alberti et al. 2011, p. 898). Peirce saw abduction as experiential and perceptual rather than simply as the conclusion of an inference (Magnani 2014, p. 178). Because abduction is the process rather than the product of inference, it draws our attention to vagueness as inability to fully explicate or rationalize the reasons behind the abduction of a particular hypothesis.

In one sense, creativity is ability to deal with the vagueness, open-endedness, and fragmentary nature of the archaeological record in new interesting and productive ways. The formation of novel hypotheses in this sense comes close to one of Matthew Johnson's definitions of the theoretical in archaeology as the order in which we put facts (Johnson 2010, p. 2, 2011, p. 768). If we take theory as a resequencing of facts, the result of this process is an emergent insight; something more than the sum of its parts. In many ways, this also resembles what Binford (2001) referred to as the use of prior knowledge in constructing multiple frames of reference. Binford (2001, p. 80), however, sees this process as inductive in nature, while I must include in any form of analogical thinking some kind of abductive element of creativity: being able to use multiple fields of knowledge or resequence the facts requires the abductive assumption of something to be true that we do not know to be true. In other words, one cannot simply resequence the facts without some kind of looseness or absence in perception and cognition. This leads us to consider abduction as an elementary companion to absence. Because of the various vacancies in archaeological data, archaeological knowledge always transcends the brute factuality of the materials. 'This is a creative process of speculative modelling which demands no hierarchy between empirical attention, analysis and leaps of the imagination' (Pearson and Shanks 2001, p. $60)$. 
Although I have highlighted the directness between perception and abduction, my intention is not to emphasise the first contact between the archaeologist and her materials. In many ways abduction, as a weak form of theorising, operates on multiple levels in archaeological reasoning, from explaining small, often surprising, details in the material, to establishing broader connections, generalisations, and analogies (Cornell and Fahlander 2002, Brück 2015, Cornell 2015). Abductions run deep, so to speak. In this way, abduction provides one possible outlook to the directionality between theory and practice in archaeology (Lucas 2015a). Because of abduction's intimate role in all reasoning from vague perceptions to grand theorising, the practice of archaeology remains essentially theoretical. I have elsewhere touched on this futureorientedness or future-situatedness of archaeological theory and practice (Marila 2014, see also Shanks 2012, p. 132-134).

\section{Archaeological finds analysis and the senses}

Archaeological theory has a long history of prioritising excavation as the locus of discovery, and the excavation has been researched and theorised from a staggeringly wide variety of perspectives: excavation as reflexive ethnography or anthropology of interpretation at 'trowel's edge' (Edgeworth 1991, 2006, Hodder 1997), excavation as performance or theatre (Tilley 1989, Pearson and Shanks 2001, see Herschend 2015 for a somewhat different perspective), excavation as discovery (Edgeworth 1991), excavation as preservation (Demoule 2011), excavation as intervention, displacement, disaggregation, and fragmentation (Lucas 2001, 2012, Jones 2002), excavation as popular archaeology and metaphor (Holtorf 2005, 2007, Thomas 2009, also Edgeworth 2013), excavation as bodily and sensorial encounter (Yarrow 2003, Edgeworth 2012), and, most importantly, excavation as archaeology's core method and ground for new knowledge (Edgeworth 2011, also Cobb et al. 2012).

Many treatments that focus on the excavation process tend to romanticise the first contact. Archaeologists often share, if implicitly, the sentiment that only through excavation the needed contextual information can be attained that is important for a meaningful finds analysis (Voss 2012, p. 146). In reality, much of the information is derived through scientific analyses and, more importantly, through painstakingly slow work by researchers that go through these materials in volumes. This is not to say that excavation is not one of the central methods that yields archaeological material. The need to excavate is particularly evident in case of some materials, especially those that are only more recently routinely collected, such as soil samples. However, the argument that excavation is the main source of archaeological knowledge reinforces the discipline's 'methodological simplification' (Nilsson 2011, p. 27, also Witmore 2004). Furthermore, archaeology of the contemporary world has on its part shifted the focus from excavation as the core method to the fact that we are surrounded by archaeologically relevant material that does not have to be excavated in the literal sense (see, for example, Harrison 2011). A large but theoretically relatively unscrutinised part of archaeology, then, is done post excavation (Deetz 
1971, Jones 2002, p. 39, 46, Witmore 2004). In contrast to the mentioned treatments on the significance of the body and the senses in the context of excavation, not to mention other aspects of archaeology varying from landscape to heritage politics (Ingold 1993, Tilley 1994, Rainbird 2008, Hamilakis 2013, 2017), relatively little attention has been given to the relevance of senses and corporeality in finds analysis explicitly (see, however, MacGregor 1999, Cummings 2002, Lazzari 2005, Hurcombe 2007, Knappett 2007, Myrberg 2010).

There is a long tradition in archaeological theory of distinguishing between the mechanical collection of data and its artistic interpretation. It can, however, be argued that finds analysis is today conceptualised as an empiricist activity where the objective is to base categorisation on quantifiable parameters. Often this involves the use of sophisticated machinery and scientific analyses performed by experts. Although in most cases it is desirable to transform these analysis results into visual and lingual media, the transformation process tends to obscure the role of senses used to gather the information; more importantly the still-existing philosophical debate between subjectivity and objectivity further complicates the matter (Baines and Brophy 2006, p. 71 , Hurcombe 2007, p. 535). This highlights the tension or discrepancy between the archaeologist's personal knowledge and the processual nature of scientific inquiry on the one hand, and the static and inductivist image of scientific conduct portrayed by the aforementioned transformation processes, most importantly by the scientific publication, on the other. Jones (2002, p. 55), for example, has voiced a concern regarding the publication of 'isolated studies:' we need to begin to create interpretative connections between different kinds of material, rather than simply study materials in isolation and then present these isolated studies in publications as objective reality; this objective approach results in fragmentation of archaeological knowledge. The discrepancy between research process and publication remains a topic worth discussing. How do we communicate and combine personal observations and knowledge? How do we communicate or expose to others the tacit dimensions of the interpretative process that led to the adoption of a particular explanation, interpretation, generalisation, or level of understanding?

Another interesting aspect to the mentioned transformation processes lies in the relationship between routine and creativity, and how unexpected traits in the studied materials occasionally break that routine and give birth to or force out new hypotheses. Again, it is not necessary to make a clear distinction between data collection and analysis or interpretation, but the distinction is a worthy analytical tool. Finds analysis is, as much as excavation or any other method, dependent on the researcher's multi-sensorial abilities and creativity in being able to combine these sensory data in a productive fashion. Some features can be seen but not felt, while others can be heard and felt but not seen. As noted by Hurcombe (2007), successful finds analysis is dependent on the use of all of our senses. Sensual encounter, according to Hurcombe, is a consideration of which of the 'attention-drawing phenomena' in the material played a role for past people, and furthermore, what qualities may be absent in the material, such as certain smells and sounds. Hurcombe (2007, p. 540) gives an interesting example concerning the way colours were 
perceived in the past, and how some distinctions that did exist in the past may go unnoticed today. This is not only evident between temporally distant cultural contexts, but it is also characteristic of the way people with different backgrounds will perceive differently today. A painter will distinguish more easily between colours and a musician will be more attuned to distinguishing small variations in pitch.

As archaeologists, however, we have to consider also those phenomena that did not draw past people's attention. Some attributes in the materials may be valuable traces or clues to understanding relations that were not of immediate significance to people in the past but are vital to answering some archaeological questions. One example of such relation would be how some vague sensory attributes in Finnish Neolithic ceramics, for example, reflect cultural realities on a larger scale [Endnote 1]. With ceramics, in addition to quantifiable factors such as clay or temper material and decorative motifs that serve as possible evidence to provenience issues and of connections between different geographical areas, we are also dealing with many non-quantifiable elements. These naturally include the decoration styles that can be coded and grouped roughly, but also more ambiguous elements. These might include some general properties of clay such as texture, feel, some visual elements such as the way some minerals in the temper reflect light, and even sound, and, literally, the smell of particular ceramic styles. Finnish Early Asbestos Ware, dated to 5000-4000 cal. BC (Mökkönen and Nordqvist 2016), for example, was commonly tempered with asbestos and talc (Fig. 1). Analysis of these materials is dependent on a variety of sensory data because a petrographic analysis of each fragment would be practically impossible. While sensory identification of borderline-cases between asbestos and talc is sometimes impossible, talc will usually make the surface feel smoother and soapier. In this sense, identification, although ambiguous and uncertain, hinges on textural qualities and feel. On the other hand, temper material, together with the decoration method and motifs, also affects how the material reflects light. Large mineral fragments with deep decorative stamp depressions will result in a lively surface that reflects light particularly vividly (Fig. 2). Every such sensory attribute is a possible clue to identifying regional and temporal variety, and therefore precursory to understanding ceramic production as an archaeological phenomenon.

Fig. 1. Eastern Finnish Early Asbestos Ware from Lappeenranta Saksanniemi settlement site (KM 12169: 98, 75, and 114). Scale is $5 \mathrm{~cm}$. Photo: Marko Marila. Produced with permission from the Finnish National Board of Antiquities.

Fig. 2. Early Asbestos Ware from Lappeenranta Saksanniemi (KM 12169: 114). Temper material and decoration motifs together affect how ceramics reflects light. Photo: Marko Marila. Produced with permission from the Finnish National Board of Antiquities.

Post-excavation material analysis can be routine-like, but every now and then one encounters something that sticks out. Often it is not possible to say precisely what the attention-drawing 
property is. The identification of some quality as possibly significant is an abductive inference at its most elementary level. Such 'surprising facts' do have a big role as clues to possible links between assemblages, for example, but sometimes they only start to make sense when one encounters them again. Some of these clues remain peculiar and even subliminal at first, and only start to make more sense when large quantities of materials are studied. Furthermore, it is not only important to go through a large volume of finds, but also related finds, such as lithic material in connection to ceramics. Only through that big picture can some local peculiarities within a find type start to make sense. Different materials support each other in the sense that some of them may reflect cultural practices, such as movement and trade connections, better than others. This knowledge then makes us look at the material assemblages differently.

The archaeologist is quickly drawn into a mixture of past technologies, practices, and processes, as well as the many possible modes of engagement and inference that need to be understood in order to make meaningful distinctions within a given set of materials (Edgeworth 1990, 2016b, Pollard 2001, Witmore 2006, Ingold 2007, Marila 2014, Moshenska 2016). In archaeological finds analysis, it is not only important to be able to distinguish between different textures or visual attributes, but to be able to decipher what processes particular features have resulted from and which of them are relevant to the question at hand (Clarke 1978, p. 14, MacGregor 1999, Bayliss and Whittle 2015, Sørensen, M.L.S. 2015). Textural variation, for instance, may be attributable to material qualities, processes of manufacture, use wear, chemical or mechanical post-depositional processes, age, finds handling, cleaning, storage, and so on (Cummings 2002, Lazzari 2005). Determining the interrelatedness of relevant processes requires not only experience and knowledge in a vast number of fields from cosmology to soil chemistry and geology, and ancient technologies to the history of museal practices, but also creativity in being able to imagine these novel associations.

Consider, for example, the many possible classes that may be constructed through artefact typology. There is undoubtedly a connection between successful typology and extensive knowledge of the totality of other objects, environments, technologies, practices, etc. belonging to the, for lack of a better word, period of study, but besides the what, equally important is the when; the material change and continuity through time and place (Sørensen, M.L.S. 2015, p. 90-91). Archaeological knowledge, as Dan Hicks puts it (2016), is made possible by revisiting a place, an idea, or an object. Therefore, finds analysis requires not only relational but also multidimensional knowledge. Through this multidimensional knowledge, it is possible to identify, for example, typological changes in the material as historically or sequentially meaningful and significant (Fowler 2017). In other words, artefact or material analysis should commence with the idea that detected differences between artefacts really do reflect past change, connections, continuity, etc., but that those differences are as much constituted by our understanding of past realities at large as knowledge of that reality is constituted by our understanding of its constituents. In finds analysis, we abductively (instinctively) seek to make sense of those, often vague, properties that 
draw our attention. Some make sense to us immediately while the peculiarities or idiosyncrasies of others are habitually inventoried for later reference. In one sense, this all calls for a type of artistic creativity, or what Jane Bennett (2012) refers to as a kind of phenomenological hoarder sensibility: diminished perception subtraction ability that enables one to grasp the rich facets of things' appearance as well as actual and potential intertwinement between materials and processes.

\section{Conclusions}

Irene Garcia-Rovira (2015) has suggested that archaeological knowledge and interpretation, after the discipline's ontological turn, could be considered as emerging from the encounter between past as a reality and past as a construction. In other words, 'the past is [...] an emerging product of work done with things' (Witmore 2014). This article argues for a somewhat similar point of view. In one sense the fragmentary nature of archaeological material gives rise to such archaeological theory and methodology that acknowledges the close relationship between the real and the constructed. Vagueness is an elementary part of archaeological knowledge formation and interpretation, and the tension between real and constructed underscores vagueness' intimate role in knowledge formation.

The rapid development of exact natural scientific methodology, together with the recent practice turn (here intended as a materialist counterpoint for the linguistic turn) in archaeological theory, has led some archaeologists to fear a radical erasure of human interpretation in favour of a return to empiricism in archaeological epistemology. The quest for exactitude through natural scientific methodology is seen by some as a 'mechanism of closure,' that, in the fashion inherent to natural sciences, aims at presenting complex data in simple representations. This division between objective data provided by natural sciences and subjective interpretations arrived at by the methods of the humanities would render the latter unreliable unless backed up by the former. In this context, vagueness is seen as a research deficiency resulting from the lack of data, rather than as an inescapable and valuable part of research. The lacking data view is a reaffirmation of naive inductivism, a position that would be untenable today. In fact, some scientifically oriented archaeologists acknowledge this problem, and, while remaining optimistic about natural scientific methods, raise some relevant questions concerning their increasing use (Müller 2013, Kristiansen 2014). Could we be facing another culture-historical archaeology, but this time dressed in natural scientific methods (Heyd 2017), or even a return to antiquarianism (Barrett 2016b)? The possibility certainly raises questions about the possibly paradigmatic nature of our discipline, and the archaeology versus scientific archaeology theme keeps resurfacing in search for the next big thing in archaeology.

If there now exists a new archaeological empiricism, its goal is not the erasure of vagueness and interpretation in pursuit of more exact data, but rather interpretation's ontological pluralisation 
and the acknowledgement of the close relationship between ontological and epistemological concerns. Archaeology remains an empirical endeavour, but the character of the new empiricism is distinct from the positivistic meaning. New forms of empiricism, both scientific and ontological, discard the naive face-value of data attitude and acknowledge the partially constructed nature of reality, as well as the open-endedness and processual character of knowledge production. This should allow us to see the methodologies of the humanities and the natural sciences as complementary. In this way, exact data and vague generalisations are bound together in a cycle that makes them mutually constitutive.

This newly found speculative archaeology, then, far from being atheoretical, urges us to speculate beyond the boundaries of our immediate experience. It is necessary for the well-being of archaeology's methodology to acknowledge speculation's importance as a methodology beyond philosophy (Willerslev 2011, Witmore 2012, Sørensen 2016). Much of geological or paleontological knowledge, for example, hinges on speculation, not least because the studied phenomena predate human existence altogether (pace Meillassoux 2008). The same applies to the archaeological record from which something unobservable is being inferred. Speculation in archaeology does not entail adopting an arm-chair attitude toward doing science. It simply states that empirical observations contain a speculative element. New archaeological knowledge is fundamentally dependent on the vagueness, the vestigial and open-ended nature of archaeological materials, and the vagueness of exact data should be acknowledged accordingly.

Turning from ontological concerns to more explicit questions of archaeology's epistemology, the article follows many other empiricist archaeologists in their rooting the emergence of new archaeological knowledge in the archaeological materials and the practice of archaeology by emphasising the importance of wide-ranging personal background knowledge. In this setting, there is a special role for so-called sedimented bodily knowledge (Shusterman 2012) and, in turn, for the vagueness or unspecificity of knowledge. Vagueness, as an empirical fact, owes much to the tacit and bodily dimensions of knowledge. Much of what we know can be attributed to the body and the senses rather than the logical or clearly articulated. This highlights the abductive roots of new knowledge. Abduction, in one sense of the word, is the realist's conceptualisation of such epistemically tacit, or at least partly tacit, processes that give rise to new knowledge. In essence, abduction is a conceptualisation of the creative and speculative elements of interpretation. This has led me to propose something along the lines of a 'speculative pragmatism' (Rosenthal 1986, Marila 2015) in archaeology. In inferring from material traces to the possible links between artefacts, technologies, actors, and processes, the archaeologist is drawn, through her involvement, into forming a series of abductive interpretations. Where vagueness explicitly enters the picture, is in how open-ended and speculative these interpretations often are. Most of the time, it is impossible to explicate why we choose one hypothesis over another. Although an important element of scientific publication, it is simply impossible to enunciate all the reasons for adopting a particular hypothesis, explanation, or generalisation. Such processes highlight the 
importance of intuition and creativity as part of scientific archaeology. A creative researcher is able to see more possible connections between the materials and imagine a more diverse collection of possible explanations and interpretations.

\section{References}

Alberti, B., 2001. Faience goddesses and ivory bull-leapers: The aesthetics of sexual difference at Late Bronze Age Knossos. World Archaeology, 33 (2), 189-205.

Alberti, B., 2016. Archaeologies of risk and wonder. Archaeological Dialogues, 23 (2), 138-145.

Alberti, B., et al., 2011. 'Worlds Otherwise': Archaeology, Anthropology, and Ontological Difference. Current Anthropology, 52 (6), 896-912.

Alberti, B., Jones, A.M., and Pollard, J., 2013. Archaeology after interpretation. Returning materials to archaeological theory. Walnut Creek, CA: Left Coast Press.

Back Danielsson, I.-M., 2015. The Social Qualia of Kuml. An exploration of the Iconicity of RuneStones with Kuml Inscriptions from the Scandinavian Late Viking Age. Current Swedish Archaeology, 23, 157-178.

Baines, A. and Brophy, K., 2006. Archaeology without -isms. Archaeological Dialogues, 13 (1), 6991.

Barrett, J.C., 2016a. Archaeology after interpretation. Returning humanity to archaeological theory. Archaeological Dialogues, 23 (2), 133-137.

Barrett, J.C., 2016b. The new antiquarianism? Antiquity, 90 (354), 1681-1686.

Bauer, A., 2013. Multivocality and 'wikiality': the epistemology and ethics of a pragmatic archaeology. In: G. Scarre and R. Coningham, eds. Appropriating the Past. Philosophical Perspectives on the Practice of Archaeology. Cambridge: Cambridge University Press, 176-194.

Bayliss, A. and Whittle, A., 2015. Uncertain on principle: combining lines of archaeological evidence to create chronologies. In: R. Chapman and A. Wylie, eds. Material Evidence: Learning from archaeological practice. London: Routledge, 213-242.

Bennett, J., 2012. Powers of the Hoard: Further Notes on Material Agency. In: J. J. Cohen, ed. Animal, Vegetable, Mineral: Ethics and Objects. Washington, DC: Oliphaunt Books, 237-269. 
Binford, L.R., 1981. Bones: Ancient Men and Modern Myths. New York: Academic Press.

Binford, L.R., 2001. Constructing Frames of Reference. An Analytical Method for Archaeological Theory Building Using Hunter-Gatherer and Environmental Data Sets. Berkeley: University of California Press.

Bintliff, J., 2011. The death of archaeological theory? In: J. Bintliff, and M. Pearce, eds. The death of archaeological theory? Oxford: Oxbow Books, 7-22.

Bintliff, J., 2015. Beyond theoretical archaeology: a manifesto for reconstructing interpretation in archaeology. In: K. Kristiansen, L. Smedja, and and Future. Essays in Honour of Evžen Neustupný. Oxford: Oxbow Books, 24-35.

Bintliff, J. and Pearce, M., eds, 2011. The death of archaeological theory? Oxford: Oxbow Books.

Bogaard, A., 2015. Lessons from modelling Neolithic farming practice: methods of elimination. In: R. Chapman and A. Wylie, eds. Material Evidence: Learning from archaeological practice. London: Routledge, 243-254.

Brück, J., 2015. The Value of Archaeology. Current Swedish Archaeology, 23, 33-36.

Bryant, L.R., 2011. The Democracy of Objects. Ann Arbor: Open Humanities Press.

Buck, C.E. and Meson, B., 2015. On being a good Bayesian. World Archaeology, 47 (4), 567-584.

Burmeister, S., 2016. Archaeological Research on Migration as a Multidisciplinary Challenge. Medieval Worlds, 4 (2016), 42-64.

Campos, D., 2011. On the distinction between Peirce's abduction and Lipton's Inference to the best explanation. Synthese 180, 419-442.

Chadha, A., 2010. Cryptographic imagination: Indus script and the project of scientific decipherment. Indian Economic Social History Review, 47 (2), 141-177.

Chiasson, P., 2001. Peirce's Logic of Vagueness. In: M. Bergman and J. Queiroz, eds. The Commens Encyclopedia: The Digital Encyclopedia of Peirce Studies. New Edition [online]. Available from: http://www.commens.org/encyclopedia/article/chiasson-phyllis-peirce\%E2\%80\%99s-logicvagueness [Accessed 1 Mar 2017].

Clarke, D.L., 1978. Analytical archaeology. London: Methuen. 
Cobb, H., et al., eds., 2012. Reconsidering Archaeological Fieldwork. Exploring On-Site

Relationships Between Theory and Practice. New York: Springer.

Cochrane, A. and Russell, I., 2007. Visualizing Archaeologies: a Manifesto. Cambridge Archaeological Journal, 17 (1), 3-19.

Copi, I.M., 1953. Introduction to Logic. New York: Macmillan.

Cornell, P., 2015. On the lack of new in archaeology or microarchaeology and grand-theory. Current Swedish Archaeology, 23, 37-45.

Cornell, P. and Fahlander, F., 2002. Microarchaeology, Materiality and Social Practice. Current Swedish Archaeology, 10, 21-38.

Crossland, Z. and Bauer, A., 2016. Im/materialities: things and signs. Semiotic Review [online], 4. Available from: http://www.semioticreview.com/index.php/thematic-issues/issueimmaterialities/48-im-materialities-things-and-signs.html [Accessed 16 Jan 2017].

Cummings, V., 2002. Experiencing texture and transformation in the British Neolithic. Oxford Journal of Archaeology, 21 (3), 249-261.

Dallas, C., 2016. Jean-Claude Gardin on Archaeological Data, Representation and Knowledge: Implications for Digital Archaeology. Journal of Archaeological Method and Theory, 23 (1), 305330.

Darvill, T., 2015. Scientia, Society, and Polydactyl Knowledge: Archaeology as s Creative Science. In: K. Kristiansen, L. Smedja, and J. Turek, eds. Paradigm Found. Archaeological theory - Present, Past and Future. Essays in Honour of Evžen Neustupný. Oxford: Oxbow Books, 6-23.

Day, J., ed., 2013. Making senses of the past. Toward a sensory archaeology. Carbondale, IL: Southern Illinois University Press.

Deetz, J., 1971. Must archaeologists dig? In: J. Deetz, ed. Man's Imprint from the Past. Boston: Little, Brown and Company, 2-9.

Demoule, J.-P., 2011. We still have to excavate - but not at any price. Archaeological Dialogues, 18 (1), 5-10. 
Doran, J., 1986. Formal Methods and Archaeological Theory: A Perspective. World Archaeology, $18(1), 21-37$.

Eco, U. and Sebeok, T.A., eds., 1983. The Sign of Three. Dupin, Holmes, Peirce. Bloomington: Indiana University Press.

Edgeworth, M., 1990. Analogy as practical reason: the perception of objects in excavation practice. Archaeological Review from Cambridge, 9 (2), 243-251.

Edgeworth, M., 1991. The Act of Discovery. An Ethnography of the Subject-Object Relation in Archaeological Practice. University of Durham.

Edgeworth, M., ed., 2006. Ethnographies of Archaeological Practice: Cultural Encounters, Material Transformations. Oxford: AltaMira Press.

Edgeworth, M., 2011. Excavation as a ground of archaeological knowledge. Archaeological Dialogues, 18 (1), 44-46.

Edgeworth, M., 2012. Follow the Cut, Follow the Rhythm, Follow the Material. Norwegian Archaeological Review, 45 (1), 76-92.

Edgeworth, M., 2013. The clearing: archaeology's way of opening the world. In: Gonzalez-Ruibal, A., ed. Reclaiming Archaeology: Beyond the tropes of modernity. London: Routledge, 33-43.

Edgeworth, M., 2016a. Grounded Objects: Archaeology and Speculative Realism. Archaeological Dialogues, 23 (1), 93-113.

Edgeworth, M., 2016b. Reverse engineering and the archaeology of flowing materials. A response to Gabriel Moshenska's paper. Forum Kritische Archäologie, 5, 31-33.

Fogelin, L., 2007. Inference to the best explanation: a common and effective form of archaeological reasoning. American Antiquity, 72 (4), 603-625.

Fowler, C., 2017. Relational Typologies, Assemblage Theory and Early Bronze Age Burials. Cambridge Archaeological Journal, 27 (1), 95-109.

Fowler, C. and Harris, O.JT., 2015. Enduring relations: Exploring a paradox of new materialism. Journal of Material Culture, 20 (2), 127-148. 
Garcia-Rovira, I., 2015. What About Us? On Archaeological Objects (Or the Objects of Archaeology). Current Swedish Archaeology, 23, 85-108.

Gell, A., 1998. Art and Agency: An Anthropological Theory. Oxford University Press.

Gero, J.M., 2007. Honoring Ambiguity/Problematizing Certitude. Journal of Archaeological Method and Theory, 14, 311-327.

Gero, J. M., 2015. Yutopian. Archaeology, Ambiguity and the Production of Knowledge in Northwest Argentina. Austin: University of Texas Press.

Gheorghiu, D. and Bouissac, P., eds, 2015. How Do We Imagine the Past? On Metaphorical Thought, Experimentality and Imagination in Archaeology. Cambridge Scholars Publishing.

Gibbon, G., 1989. Explanation in archaeology. Oxford: Basil Blackwell.

Gosden, C., 2001. Making Sense: Archaeology and Aesthetics. World Archaeology, 33 (2), 163167.

Gosden, C. and Malafouris, L., 2015. Process archaeology (P-Arch). World Archaeology, 47 (5), 701-717.

Graves-Brown, P., 2011. Touching from a Distance: Alienation, Abjection, Estrangement and Archaeology. Norwegian Archaeological Review, 44 (2), 131-144.

Graves-Brown, P., 2013. Inside is out: An epistemology of surfaces and substances. In: GonzalezRuibal, A., ed. Reclaiming Archaeology: Beyond the tropes of modernity. London: Routledge, 298310.

Haack, S., 1994. How the Critical Common-sensist Sees Things. Histoire Épistémologie Langage Année, 16 (1), 9-34.

Hamilakis, Y., 2013. Archaeology and the Senses: Human Experience, Memory, and Affect. New York: Cambridge University Press.

Hamilakis, Y., 2017. Sensorial Assemblages: Affect, Memory and Temporality in Assemblage Thinking. Cambridge Archaeological Journal, 27 (1), 169-182.

Hamilakis, Y., Pluciennik, M., and Tarlow, S., eds., 2002. Thinking through the Body: Archaeologies of Corporeality. New York: Kluwer Academic/Plenum Publishers. 
Hanen, M. and Kelley, J., 1989. Inference to the best explanation in archaeology. In: V. Pinsky and A. Wylie, eds. Critical Traditions in Contemporary Archaeology. Essays in the Philosophy, History and Socio-Politics of Archaeology. Albuquerque: University of New Mexico Press, 14-17.

Hanson, N.R., 1958 (1972). Patterns of discovery. An Inquiry into the Conceptual Foundations of Science. Cambridge University Press.

Harman, G., 1965. The inference to the best explanation. The Philosophical Review, 74 (1), 88-95.

Harman, G., 2005. Guerrilla Metaphysics. Phenomenology and the Carpentry of Things. Chicago: Open Court.

Harman, G., 2007. On Vicarious Causation. In: R. Mackay, ed. Collapse II. Speculative Realism. Falmouth, UK: Urbanomic, 171-206.

Harrison, R., 2011. Surface assemblages. Towards an archaeology in and of the present. Archaeological Dialogues, 18 (2), 141-161.

Herschend, F., 2015. Archaeology is history or it's history. In: C. Hillerdal and J. Siapkas, eds. Debating Archaeological Empiricism: The Ambiguity of Material Evidence. New York: Routledge, 125-137.

Herva, V.-P., Mökkönen, T., and Nordqvist, K., 2017. A Northern Neolithic? Clay Work, Cultivation and Cultural Transformations in the Boreal Zone of North-Eastern Europe, c. 5300-3000 BC. Oxford Journal of Archaeology, 36 (1), 25-41.

Herva, V-P. and Nordin, J.M., 2015. Unearthing Atlantis and performing the past: Ancient things, alternative histories and the present past in the Baroque world. Journal of Social Archaeology, 15 (1), 116-135.

Herva, V.-P., Nordqvist, K., Lahelma, A., and Ikäheimo, J., 2014. Cultivation of Perception and the Emergence of the Neolithic World. Norwegian Archaeological Review, 47 (2), 141-160.

Heyd, V., 2017. Kossinna's Smile. Antiquity, 91 (356), 348-359.

Hicks, D., 2016. The Temporality of the Landscape Revisited. Norwegian Archaeological Review, $49(1), 5-22$. 
Hillerdal, C. and Siapkas, J., eds, 2015. Debating Archaeological Empiricism: The Ambiguity of Material Evidence. New York: Routledge.

Hodder, I., 1991. Interpretive Archaeology and Its Role. American Antiquity, 56 (1), 7-18.

Hodder, I., 1997. "Always Momentary, Fluid and Flexible": Towards a Reflexive Excavation Methodology. Antiquity, 71 (273), 691-700.

Hodder, I., 2012. Entangled: An Archaeology of the Relationships between Humans and Things. Chichester, West Sussex: Wiley-Blackwell.

Hodder, I. and Mol, A., 2016. Network Analysis and Entanglement. Journal of Archaeological Method and Theory, 23 (4), 1066-1094.

Holtorf, C., 2005. From Stonehenge to Las Vegas - Archaeology as popular culture. Walnut Creek: AltaMira Press.

Holtorf, C., 2007. Archaeology is a brand. Walnut Creek: Left Coast Press.

Hurcombe, L., 2007. A sense of materials and sensory perception in concepts of materiality. World Archaeology, 39 (4), 532-545.

Ingold, T. 1993. The temporality of the landscape. World Archaeology, 25 (2), 152-174.

Ingold, T., 2007. Materials against materiality. Archaeological Dialogues, 14 (1), 1-16.

Ingold, T., 2013. Making. Anthropology, archaeology, art and architecture. London: Routledge.

Johnson, M., 2010. Archaeological theory: an introduction. Malden, MA: Wiley-Blackwell.

Johnson, M., 2011. On the nature of empiricism in archaeology. Journal of the Royal Anthropological Institute, 17, 764-787.

Jones, A., 2002. Archaeological theory and scientific practice. Cambridge University Press.

Jones, A., 2006. Animated Images: Images, Agency and Landscape in Kilmartin, Argyll, Scotland. Journal of Material Culture, 11 (1), 211-225.

Kelley, J. and Hanen, M., 1988. Archaeology and the Methodology of Science. Albuquerque: University of New Mexico Press. 
Killick, D.J., 2015. The awkward adolescence of archaeological science. Journal of Archaeological Science, 56, 242-247.

Klejn, L., 2001. Metaarchaeology. Acta Archaeologica, 72 (1), 1-150.

Knappett, K., 2007. Materials with materiality? Archaeological Dialogues, 14 (1), 20-23.

Knappett, K. and Malafouris, L., eds, 2008. Material agency. Towards a Non-Anthropocentric Approach. New York: Springer.

Kolen, J., 2011. A new empiricism. Excavating at the start of the 21st century. Archaeological Dialogues, 18 (1), 30-41.

Kristiansen, K., 2014. Towards a New Paradigm? The Third Science Revolution and its Possible Consequences in Archaeology. Current Swedish Archaeology, 22, 11-34.

Lazzari, M., 2005. The texture of things: objects, people and landscape in Northwest Argentina (First Millennium A.D.). In: L. Meskell, ed. Archaeologies of Materiality. Oxford: Blackwell, 126161.

Lipton, P., 1991. Inference to the Best Explanation. London: Routledge.

Lucas, G., 2001. Destruction and the Rhetoric of Excavation. Norwegian Archaeological Review, $34(1), 35-46$.

Lucas, G., 2012. Understanding the archaeological record. Cambridge University Press.

Lucas, G., 2015a. The Mobility of Theory. Current Swedish Archaeology, 23, 13-32.

Lucas, G., 2015b. Debating Archaeological Empiricism. Some Closing Comments. In: C. Hillerdal and J. Siapkas, eds. Debating Archaeological Empiricism: The Ambiguity of Material Evidence. New York: Routledge, 188-192.

MacGregor, G., 1999. Making Sense of the past in the Present: A Sensory Analysis of Carved Stone Balls. World Archaeology, 31 (2), 258-271.

Madella, M., et al., 2014. Introduction to Simulating the Past. Journal of Archaeological Method and Theory, 21, 251-257. 
Magnani, L., 2004. Model-based and manipulative abduction in science. Foundations of Science, 9 (3), 219-247.

Magnani, L., 2009. Abductive Cognition. The Epistemological and Eco-Cognitive Dimensions of Hypothetical Reasoning. Berlin: Springer.

Magnani, L., 2010. Mindless Abduction: From Animal Guesses to Artifactual Mediators. In: M. Bergman, S. Paavola, A.-V. Pietarinen, and H. Rydenfelt, eds. Ideas in Action: Proceedings of the Applying Peirce Conference, 11-13 June 2007 Helsinki. Helsinki: Nordic Pragmatism Network, 224-238.

Magnani, L., 2014. Understanding Abduction. Inference, Perception and Instinct. In: L. Magnani, ed. Model-Based Reasoning in Science and Technology: Theoretical and Cognitive Issues.

Heidelberg: Springer, 173-205.

Malafouris, L. and Renfrew, C., eds, 2010. The Cognitive Life of Things. Recasting the boundaries of the mind. Cambridge: McDonald Institute for Archaeological Research.

Marila, M., 2014. Things in Action - Interpreting the Meanings of Things in Archaeology. In: Ikäheimo, J., Salmi, A.-K., and Äikäs, T., eds. Sounds Like Theory. XII Nordic Theoretical Archaeology Group Meeting, 25-28 April 2012 Oulu. Helsinki: Archaeological Society of Finland, 9-20.

Marila, M., 2015. Pragmaticism - the new possibility of a scientific archaeology as seen in the light of the history of archaeology. Interarchaeologia, 4, 197-217.

Martinón-Torres, M. and Killick, D., Forthcoming. Archaeological Theories and Archaeological Sciences. In: A. Gardner, M. Lake, and U. Sommer, eds. The Oxford Handbook of Archaeological Theory. Oxford University Press.

Meillassoux, Q., 2008. After Finitude. An Essay on the Necessity of Contingency. London: Continuum.

Meredith, J., 1990. The aesthetic artefact: an exploration of emotional response and taste in archaeology. Archaeological Review from Cambridge, 9 (2), 208-217.

Meskell, L., 1996. The somatization of archaeology: Institutions, discourses, corporeality. Norwegian Archaeological Review, 29 (1), 1-16. 
Meskell, L. and Joyce, R., 2003. Embodied lives. Figuring ancient Maya and Egyptian Experience. London: Routledge.

Minnameier, G. 2004. Peirce-suit of truth - Why inference to the best explanation and abduction ought not to be confused. Erkenntnis 60, 75-105.

Mizoguchi, K., 2015. How we have come to do archaeology the way(s) we do: a meta-critique of current archaeological discursive formation. In: K. Kristiansen, L. Smedja, and J. Turek, eds. Paradigm Found. Archaeological theory - Present, Past and Future. Essays in Honour of Evžen Neustupný. Oxford: Oxbow Books, 147-155.

Moshenska, G., 2016. Reverse engineering and the archaeology of the modern world. Forum Kritische Archäologie, 5, 16-28.

Mullins, P., 2002. Peirce's Abduction and Polanyi's Tacit Knowing. The Journal of Speculative Philosophy, 16 (3), 198-224.

Müller, J., 2013. Kossinna, Childe and aDNA. Comments on the construction of identities. Current Swedish Archaeology, 21, 35-37.

Myrberg, N., 2010. The Colour of Money. Crusaders and coins in the thirteenth-century Baltic Sea. In: F. Fahlander and A. Kjellström, eds. Making Sense of Things: Archaeologies of Sensory Perception, 26-27 November 2009 Stockholm. Stockholm Studies in Archaeology, 53. Stockholm University, 83-102.

Mökkönen, T. and Nordqvist, K., 2016. Quantifying Mineral Raw Materials in Neolithic Knapped Tool Production in the Lake Saimaa Area, Finnish Inland. In: P. Uino and K. Nordqvist, eds. Iskos 21. New Sites, New Methods. Proceedings of the Finnish-Russian Archaeological Symposium. 19-21 November 2015 Helsinki. Helsinki: The Finnish Antiquarian Society, 41-58.

Nilsson, B., 2011. Archaeology and the unstoppable excavation machine. A Swedish point of view. Archaeological Dialogues, 18 (1), 26-29.

Nordqvist, K., 2016. From separation to interaction. Corded Ware in the Eastern Gulf of Finland. Acta Archaeologica, 87 (1), 49-84.

Nordqvist, K. and Mökkönen, T., 2015. Äyräpää's Typical Comb Ware: an umbrella term for the early 4th millennium BC pottery in Northeastern Europe. Fennoscandia archaeologica, XXXII, $151-158$. 
Nordqvist, K. and Mökkönen, T., 2016. A Stone Age Strainer from the Northern Boreal Zone: A Find from Pegrema I (Karelian Republic). Fennoscandia archaeologica, XXXIII, 231-236.

Normark, J., 2010. Face/Off: A Neomaterialist Study of the Face. In: F. Fahlander and A. Kjellström, eds. Making Sense of Things: Archaeologies of Sensory Perception, 26-27 November 2009 Stockholm. Stockholm Studies in Archaeology, 53. Stockholm University, 69-82.

Olsen, B., 2003. Material Culture after Text: Re-Membering Things. Norwegian Archaeological Review, 36 (2), 87-104.

Olsen, B., 2010. In Defense of Things. Archaeology and the Ontology of Objects. Lanham: AltaMira Press.

Olsen, B., 2012. After Interpretation: Remembering Archaeology. Current Swedish Archaeology, 20: 11-34.

Olsen, B. and Pétursdóttir, P., eds, 2014. Ruin Memories. Materiality, Aesthetics and the Archaeology of the Recent Past. London: Routledge.

Olsen, B., et al., 2012. Archaeology. The Discipline of Things. Berkeley: University of California Press.

Olsen, B. and Witmore, C., 2015. Archaeology, symmetry and the ontology of things. A response to critics. Archaeological Dialogues, 22 (2), 187-197.

Paavola, S., 2006. Hansonian and Harmanian Abduction as Models of Discovery. International Studies in the Philosophy of Science, 20 (1), 93-108.

Pearson, M. and Shanks, M., 2001. Theatre/archaeology. London: Routledge.

Peirce, C.S., 1932. The Collected Papers of Charles Sanders Peirce. Volume 2: Elements of Logic. Edited by C. Hartshorne and P. Weiss. Cambridge: Harvard University Press.

Peirce, C.S., 1933. The Collected Papers of Charles Sanders Peirce. Volume 4: The Simplest Mathematics. Edited by C. Hartshorne and P. Weiss. Cambridge: Harvard University Press.

Peirce, C.S., 1934. The Collected Papers of Charles Sanders Peirce. Volume 5: Pragmatism and Pragmaticism. Edited by C. Hartshorne and P. Weiss. Cambridge: The Belknap Press of Harvard University Press. 
Peirce, C.S., 1958. The Collected Papers of Charles Sanders Peirce. Volume 7: Science and Philosophy. Edited by A.W. Burks. Cambridge: The Belknap Press of Harvard University Press.

Peirce, C.S., 1997. Pragmatism as a Principle and Method of Right Thinking: The 1903 Harvard Lectures on Pragmatism. Edited by P.A. Turrisi. Albany: State University of New York Press.

Pétursdóttir, D. and Olsen, B., 2014. Imaging Modern Decay: The Aesthetics of Ruin Photography. Journal of Contemporary Archaeology, 1 (1), 7-56.

Plog, F.T., 1974. The study of Prehistoric change. New York: Academic Press.

Pollard, J., 2001. The Aesthetics of Depositional Practice. World Archaeology, 33 (2), 315-333.

Preucel, R.W., 2006. Archaeological Semiotics. Malden, MA: Blackwell.

Rainbird, P., 2008. The body and the senses: implications for landscape archaeology. In: B. David and J. Thomas, eds. Handbook of landscape archaeology. Walnut creek: Left Coast Press, 263270 .

Ribeiro, A., 2016. Archaeology will be just fine. Archaeological Dialogues, 23 (2), 146-151.

Robb, J., 2013. Material Culture, Landscapes of Action, and Emergent Causation. A New Model for the Origins of the European Neolithic. Current Anthropology, 54 (6), 657-683.

Rosenthal, S.B., 1986. Speculative pragmatism. Amherst: The University of Massachusetts Press.

Routledge, B., 1995. 'For the sake of argument': reflections on the structure of argumentation in Syro-Palestinian archaeology. Palestine Exploration Quarterly, 127, 41-49.

Serres, M., 1995. Genesis. Ann Arbor: The University of Michigan Press.

Shanks, M., 1990. Conclusion: Reading the Signs: Responses to Archaeology after Structuralism. In: I. Bapty and T. Yates, eds. Archaeology after structuralism. Post-structuralism and the Practice of Archaeology. London: Routledge, 294-310.

Shanks, M., 1992. Experiencing the past. On the character of archaeology. London: Routledge.

Shanks, M., 1995. Archaeological experiences and a critical romanticism. In: M. Tusa and T. Kirkinen, eds. Nordic TAG. The Archaeologist and His/Her Reality. Report from the fourth Nordic TAG conference Helsinki 1992. Helsinki Papers in Archaeology, 7, 17-36. 
Shanks, M., 1996. Classical archaeology of Greece. Experiences of the discipline. London: Routledge.

Shanks, M., 2012. The Archaeological Imagination. Walnut Creek, CA: Left Coast Press.

Shanks, M. and McGuire, R.H., 1996. The Craft of Archaeology. American Antiquity, 61 (1), 75-88.

Shapland, A., 2010. The Minoan lion: presence and absence on Bronze Age Crete. World Archaeology, 42 (2), 273-289.

Shelley, C., 1996. Visual abductive reasoning in archaeology. Philosophy of Science, 63, 278-301.

Shusterman, R., 2012. Thinking Through the Body. Essays in Somaesthetics. Cambridge University Press.

Sørensen, M.L.S., 2015. 'Paradigm Lost' - On the state of typology within archaeological theory. In: K. Kristiansen, L. Smedja, and J. Turek, eds. Paradigm Found. Archaeological theory - Present, Past and Future. Essays in Honour of Evžen Neustupný. Oxford: Oxbow Books, 84-94.

Sørensen, T.F., 2012. Delusion and disclosure: human disposal and the aesthetics of vagueness. In: M.L.S. Sørensen and K. Rebay-Salisbury, eds. Embodied Knowledge. Perspectives on Belief and Technology. Oxford: Oxbow Books, 27-39.

Sørensen, T.F., 2015. More than a feeling: Towards an archaeology of atmosphere. Emotion, Space and Society, 15, 64-73.

Sørensen, T.F., 2016. In Praise of Vagueness: Uncertainty, Ambiguity and Archaeological Methodology. Journal of Archaeological Method and Theory, 23 (2), 741-763.

Thomas, J., 2009. Sigmund Freud's archaeological metaphor and archaeology's selfunderstanding. In: C. Holtorf and A. Piccini, eds. Contemporary archaeologies: excavating now. Frankfurt am Main: Peter Lang, 33-45.

Thomas, J., 2015. The future of archaeological theory. Antiquity, 89 (348), 1287-1296.

Thomas, R.M., 2015. Evidence, archaeology and law: an initial exploration. In: R. Chapman and A. Wylie, eds. Material Evidence: Learning from archaeological practice. London: Routledge, 255270. 
Tiercelin, C., 2005. Abduction and the semiotics of perception. Semiotica, 153 (1), 389-412.

Tilley, C., 1989. Excavation as theatre. Antiquity, 63 (239), 275-280.

Tilley, C., 1994. A Phenomenology of Landscape. Places, Paths and Monuments. Oxford: Berg.

Tilley, C., 2004. The Materiality of Stone. Explorations in Landscape Phenomenology: 1. Oxford: Berg.

Voss, B.L., 2012. Curation as research. A case study in orphaned and underreported archaeological collections. Archaeological Dialogues, 19 (2), 145-169.

Webmoor, T., 2007. What about 'one more turn after the social' in archaeological reasoning? Taking things seriously. World Archaeology, 39 (4), 563-578.

Webmoor, T. 2013. STS, symmetry, archaeology. In: P. Graves-Brown, R. Harrison and A. Piccini, eds. The Oxford Handbook of the Archaeology of the Contemporary World. Oxford University Press, 105-120.

Webmoor, T. and Witmore, C.L., 2008. Things Are Us! A Commentary on Human/Things Relations under the Banner of a 'Social' Archaeology. Norwegian Archaeological Review, 41 (1), 53-70.

Whitehead, A.N., 1978. Process and Reality. New York: The Free Press.

Willerslev, R., 2011. Frazer strikes back from the armchair: a new search for the animist soul. Journal of the Royal Anthropological Institute, 17, 504-526.

Willey, G.R. and Phillips, P., 1958. Method and theory in American archaeology. University of Chicago Press.

Witmore, C., 2004. On multiple fields. Between the material world and media: two cases from the Peloponnesus, Greece. Archaeological Dialogues, 11 (2), 133-164.

Witmore, C., 2006. Vision, Media, Noise and the Percolation of Time: Symmetrical Approaches to the Mediation of the Material World. Journal of Material Culture, 11 (3), 267-292.

Witmore, C., 2009. Prolegomena to Open Pasts: On Archaeological Memory Practices. Archaeologies: Journal of the World Archaeological Congress, 5 (3), 511-545. 
Witmore, C., 2012. The Realities of the Past: Archaeology, Object-Orientations, Pragmatology. In: B. Fortenberry and L. McAtackney, eds. Modern Materials: The Proceedings of CHAT Oxford, 2009. Studies in Contemporary and Historical Archaeology 8. Oxford: Archaeopress, 25-36.

Witmore, C., 2014. Archaeology and the New Materialisms. Journal of Contemporary Archaeology, 1 (2), 203-246.

Witmore, C., 2015. Archaeology and the Second Empiricism. In: C. Hillerdal and J. Siapkas, eds. Debating Archaeological Empiricism: The Ambiguity of Material Evidence. New York: Routledge, 3761.

Wylie, A., 2002. Thinking from Things: Essays in the Philosophy of Archaeology. Berkeley: University of California Press.

Yarrow, T., 2003. Artefactual Persons: The Relational Capacities of Persons and Things in the Practice of Excavation. Norwegian Archaeological Review, 36 (1), 65-73.

Notes

[1] Many of the examples concerning finds analysis mentioned in this chapter derive from a discussion between the author, and Teemu Mökkönen and Kerkko Nordqvist, who studied a mass of ceramic and lithic material from Finland and Russian Karelia as part of a four-year research project 'The Use of Materials and the Neolithisation of North-Eastern Europe c. 6000-1000 BC' (e.g. Herva et al. 2014, 2017, Nordqvist and Mökkönen 2015, 2016, Mökkönen and Nordqvist 2016, Nordqvist 2016). 